\title{
Brucella Laboratory Exposures in Brazil: Rare or Unnoticed?
}

\author{
Felipe Francisco Tuon, ${ }^{1 *}$ Juliana Clelia Cequinel, ${ }^{2}$ Keite da Silva Nogueira, ${ }^{3}$ and Guilherme Nardi Becker ${ }^{4}$ \\ ${ }^{1}$ Laboratory of Emerging Infectious Diseases, School of Medicine, Pontifícia Universidade Católica do Paraná, Curitiba, Brazil; ${ }^{2}$ Secretaria de \\ Estado da Saúde do Paraná, Curitiba, Brazil; ${ }^{3}$ Hospital de Clínicas, Universidade Federal do Paraná, Curitiba, Brazil; ${ }^{4}$ Laboratorio Central do \\ Estado, São Jose dos Pinhais, Brazil
}

\begin{abstract}
Laboratory exposures to Brucella spp. are preventable. After an outbreak in Brazil, human brucellosis was made statutorily reportable as well as laboratory accidents. After the implementation of this law, three laboratorial accidents with Brucella abortus were reported in a Brazilian city, and 58 workers were exposed from January 2019 to April 2020. We describe the exposure level, prophylaxis, and serosurvey after 6 months, and we highlight the importance of disease report.
\end{abstract}

Human brucellosis (HB) is a zoonotic bacterial infection caused by Brucella spp. and is transmitted from several sources to humans. The primary sources are cattle, sheep, goats, and pigs, which transmit the microorganism to humans through direct contact with infected animals or ingestion of contaminated food products. ${ }^{1}$ In Brazil, brucellosis in cows, dogs, buffalos, sheep, goats, deer, horses, dolphin, and other animals has been reported. ${ }^{2}$ Human cases have been described sporadically; however, serosurvey studies suggest that the infection is more prevalent than reported. ${ }^{3,4}$ Since the first case that was published in Brazil in 1934, ${ }^{5} \mathrm{HB}$ has been reported throughout the country, but it is generally restricted to workers of slaughterhouses, consumers of unpasteurized milk from areas of a high incidence of bovine brucellosis, and agricultural workers. Only one study reported a laboratory-acquired infection, but no other laboratory accidents have been reported. ${ }^{6}$ The aim of this study was to highlight the importance of the disease report to the state health organization, improving detection of laboratory accidents.

In May 2015, HB was made statutorily reportable in Parana, Brazil. A working group was established to restructure and upgrade the State Protocol on HB. We convened a panel of 20 experts, including specialists in infectious diseases, biologists, veterinary specialists, laboratory specialists, epidemiologists, and pharmacists from the State of Paraná, Brazil. ${ }^{7}$ All probable or laboratory-confirmed new brucellosis cases were required to be reported. This decision was taken by the State Department of Health of Parana (SDHP) because of an outbreak comprising $51 \mathrm{HB}$ cases in a slaughterhouse at Paiçandu in 2014, previously reported by our group. ${ }^{2}$ Active surveillance of human cases was established and serum tests tracked by the SDHP zoonosis division.

After the implementation of this work group, three laboratory accidents were identified in the city, occurring in different laboratories from January 2019 to April 2020. All of them were not enabled to manipulate with Brucella spp.; however, the isolates were misunderstood in the routine as other Gram-negative bacilli. The clinical samples (blood

*Address correspondence to Felipe Francisco Tuon, Escola de Medicina, Pontifícia Universidade Católica do Paraná, R. Imaculada Conceição, 1155 - Prado Velho, Curitiba 80215-901, Brazil. E-mail: felipe.tuon@pucpr.br culture) had not any mention of the possibility of Brucella spp. Consequently, laboratory technicians managed the samples following the usual procedures, such as smearing and sniffing the colonies outside of a biosafety cabinet. The pathogen was subsequently identified as Brucella abortus using real-time PCR and matrix-assisted laser desorption/ionization time-of-flight Vitek MS (BioMérièux, Durham, NC).

In three laboratories, 58 workers were exposed in different levels of exposition, most of them could be considered as high risks, like sniffing the plate with the bacteria $(n=37,63.7 \%)$, work in the same room without an adequate biosafety level (100\%) (Table 1). The most substantial review about this issue is that 167 workers were exposed in 28 laboratories in nine countries between 1985 and $2006 .{ }^{8}$ However, the number of symptomatic infection was low (5\%). In our survey, no worker developed the disease. The serology was performed, and the tests were negative. The antibiotic postexposure prophylaxis (PEP) was not performed according to CDC recommendation with doxycycline. ${ }^{9}$ Only 53 workers $(91.3 \%)$ received 21 days of PEP.

Laboratory exposures to Brucella spp. is a preventable public health problem. The exposures described earlier were caused by routine work with clinical specimens where brucellosis was not suspected. It should be remembered that all unknown specimens be manipulated in a biological safety cabinet until a highly infectious pathogen is ruled out. The exposure to Brucella spp. must receive prophylaxis according to current recommendations. Furthermore, monitoring for any highly infectious pathogen should be continuously performed to protect the health of laboratory workers. The implementation a working group on brucellosis allowed for improvement in the detection of laboratory accidents, probably never previously notified.

Received May 12, 2020. Accepted for publication July 29, 2020.

Published online September 8, 2020.

Authors' addresses: Felipe Francisco Tuon, Infectious Diseases, Pontifícia Universidade Católica do Paraná, Curitiba, Brazil, E-mail: flptuon@gmail.com. Juliana Clelia Cequinel, Zoonotic Diseases, Secretaria de Estado da Saúde do Paraná, Curitiba, Brazil, E-mail: juliana.cequinel@sesa.pr.gov.br. Keite da Silva Nogueira, Microbiology, Universidade Federal do Paraná, Curitiba, Brazil, E-mail: keitenogueira@gmail.com. Guilherme Nardi Becker, Molecular Biology, Laboratorio Central do Estado, Sao Jose dos pinhais, Brazil, E-mail: guinbecker@gmail.com. 
TABLE 1

Description of three laboratory accidents with Brucella spp. in the Curitiba city between January 2019 and April 2020

\begin{tabular}{|c|c|c|c|c|c|c|c|c|c|}
\hline Laboratory & $\begin{array}{c}\text { Number } \\
\text { of } \\
\text { workers }\end{array}$ & $\begin{array}{l}\text { Sniffed or opened } \\
\text { the culture plate } \\
\text { using a maximum of } \\
\text { biosafety level-2 } \\
\text { precautions }\end{array}$ & $\begin{array}{l}\text { Person performing } \\
\text { activity and any } \\
\text { person within a 5-ft } \\
\text { radius }\end{array}$ & $\begin{array}{l}\text { All persons present } \\
\text { in the laboratory } \\
\text { room with aerosol } \\
\text { generating } \\
\text { procedures }\end{array}$ & $\begin{array}{c}\text { Present in the } \\
\text { laboratory at the } \\
\text { time of manipulation } \\
\text { of a Brucella isolate } \\
\text { on an open bench, } \\
\text { but who do not have } \\
\text { high-risk exposures } \\
\text { as defined } \\
\text { previously }\end{array}$ & $\begin{array}{l}\text { Positive } \\
\text { serum test to } \\
\text { Brucella }\end{array}$ & $\begin{array}{l}\text { Serum test } \\
\text { collected } \\
\text { after } \\
\text { exposure }\end{array}$ & $\begin{array}{c}\text { Antibiotic } \\
\text { prophylaxis }\end{array}$ & Follow-up (6 months) \\
\hline$\# 1$ & 31 & $12 / 31(38.7 \%)$ & $12 / 31(38.7 \%)$ & $24 / 31(77.4 \%)$ & $31 / 31(100 \%)$ & $0 / 31(0 \%)$ & $\begin{array}{l}\text { Between } \\
60 \text { and } \\
70 \text { days }\end{array}$ & $31 / 31(100 \%)$ & $\begin{array}{l}\text { All } \\
\text { asymptomatic }\end{array}$ \\
\hline \#2 & 5 & $3 / 5(60 \%)$ & $5 / 5(100 \%)$ & $0 / 5(0 \%)$ & $5 / 5$ (100\%) & $0 / 5(0 \%)$ & $\begin{array}{l}\text { Days } 30, \\
60, \text { and } \\
90 \text { days }\end{array}$ & $0 / 5(0 \%)$ & $\begin{array}{l}\text { All } \\
\text { asymptomatic }\end{array}$ \\
\hline \#3 & 22 & $22 / 22(100 \%)$ & $22 / 22(100 \%)$ & 0/22 (0\%) & 0/22 (0\%) & $0 / 22(0 \%)$ & - & $22 / 22(100 \%)$ & $\begin{array}{l}\text { All } \\
\quad \text { asymptomatic }\end{array}$ \\
\hline Total & 58 & $37 / 58$ (63.7\%) & $39 / 58$ (67.2\%) & 24/58 (41.3\%) & $36 / 58$ (62.0\%) & $0 / 58(0 \%)$ & - & $53 / 58$ (91.3\%) & - \\
\hline
\end{tabular}

\section{REFERENCES}

1. Pappas G, Papadimitriou P, Akritidis N, Christou L, Tsianos EV, 2006. The new global map of human brucellosis. Lancet Infect Dis 6: 91-99.

2. Lemos TS, Cequinel JC, Costa TP, Navarro AB, Sprada A, Shibata FK, Gondolfo R, Tuon FF, 2018. Outbreak of human brucellosis in southern Brazil and historical review of data from 2009 to 2018. PLoS Negl Trop Dis 12: e0006770.

3. Garcia JL, Navarro IT, 2001. Serologic survey for leptospirosis and brucellosis in patients from the rural area of Guaraci county, Parana state, Brazil [article in Portuguese]. Rev Soc Bras Med Trop 34: 301-302.

4. Angel MO, Ristow P, Ko Al, Di-Lorenzo C, 2012. Serological trail of Brucella infection in an urban slum population in Brazil. $J$ Infect Dev Ctries 6: 675-679.
5. Pacheco G, de MM, 1950. Human brucellosis in Brazil [article in Undetermined language]. Mem Inst Oswaldo Cruz 48: 393-436.

6. Rodrigues AL, Silva SK, Pinto BL, Silva JB, Tupinambas U, 2013. Outbreak of laboratory-acquired Brucella abortus in Brazil: a case report. Rev Soc Bras Med Trop 46: 791-794.

7. Tuon FF, Cerchiari N, Cequinel JC, Droppa EEH, Moreira SDR, Costa TP, Navarro APB, Handar AM, Souza MN, Brucellosis W, 2017. Guidelines for the management of human brucellosis in the State of Parana, Brazil. Rev Soc Bras Med Trop 50: 458-464.

8. Traxler RM, Lehman MW, Bosserman EA, Guerra MA, Smith TL, 2013. A literature review of laboratory-acquired brucellosis. J Clin Microbiol 51: 3055-3062.

9. Traxler RM et al., 2013. Review of brucellosis cases from laboratory exposures in the United States in 2008 to 2011 and improved strategies for disease prevention. J Clin Microbiol 51: 3132-3136. 